\title{
Effect of lysine intake and feeding level during rearing on growth performance of laying-type pullets
}

\author{
R. P. Kwakkel ${ }^{1}$, P. C. M. Z. Corijn ${ }^{2}$ and M. Bruining ${ }^{1}{ }^{1}$ Department of Animal \\ Nutrition, Agricultural University, Haagsteeg 4, NL 6708 PM Wageningen, Ne- \\ therlands; ${ }^{2}$ Trouw \& Co. B.V. International, Nijverheidsweg 2, NL 3881 LA Put- \\ ten, Netherlands)
}

\section{Received 15 January 1988; accepted 9 March 1988}

\begin{abstract}
Effects of a conventional step-down lysine regime (0-18 weeks of age), a step-up lysine regime ( $0-18$ weeks of age) and a quantitative 'mid-term' restriction (7-15 weeks of age) on weight development and feed consumption in 640 layingtype pullets were studied. Digestible lysine levels of the diet varied according to the experimental regime between 0.57 and $0.85 \%$ during the rearing phases. Applied 'mid-term' restriction was $85 \%$ of ad libitum. Whereas no differences in body weight at 18 weeks of age could be demonstrated between the feeding regimes, some regimes decreased feed consumption during rearing to a maximum of $7 \%$, due to the changed pattern of weight development.
\end{abstract}

Keywords: lysine, body weight development, step-up, restricted feeding, growth, laying-type pullets

Introduction. Over the last few years, the laying performance of leghorn strains used for egg production has been changed genetically (Leeson, 1986). Therefore it is necessary to revaluate the feeding programmes during rearing on their suitability for the modern hen.

The weight of a hen at 18 weeks of age is thought to be a reliable parameter to predict subsequent laying performance (Wells, 1980). Achieving this weight through a conventional step-down feeding programme (Scott et al., 1982) is a good insurance to obtain a profitable hen. Summers \& Leeson (1978) assumed from their experiments on diet self-selection that the nutritional demands of a young pullet reflect its physiological requirements. They promoted the use of a 'reverse protein' feeding strategy during rearing; this is referred to as the step-up method. With this method a more 'optimum' development of the hen's body size, in addition to its target weight, can be achieved (Leeson \& Summers, 1979). On the other hand, Wells (1980) claimed that a 'mid-term' feed restriction is an 'economic' method for rearing the modern pullet, that still achieves the desired production goals.

These considerations led to this study of the effect of step-down, step-up or 'midterm' restricted feeding strategies on body weight development, feed consumption and feed conversion ratio (FCR) of growing pullets. According to data of Scott et al. (1982), lysine was the first limiting amino acid used in the experimental diets. Therefore lysine was used as 'growth'-controlling factor in the step-wise rearing treatments. 
Material and methods. A total of 640 one-day-old white leghorn pullets were housed during rearing in battery cages (16 pullets per cage) and submitted randomly to 8 treatments (Table 1). Pullets of Treatments 1 and 2 were subjected to a stepdown lysine programme; those of Treatments 3 and 4 were reared on a step-up lysine programme. As stated in Table 1, pullets of Treatments 1-4 were fed ad libitum (AL). Pullets of Treatments 5-8 were fed a $0.85 \%$ digestible lysine starter diet from 0-6 weeks of age, followed by a 'mid-term' restricted feed intake of a normal grower diet (R: $85 \%$ of AL) from 7-15 weeks of age. Table 1 shows the digestible lysine contents of the experimental diets. Lysine levels of the starter (0-6 weeks: $19.6 \%$ crude protein $\left.(\mathrm{CP}), 11.7 \mathrm{MJ} \mathrm{ME} \mathrm{kg}^{-1}\right)$ and grower (7-18 weeks: $17.3 \% \mathrm{CP}$, 11.7 MJ ME $\mathrm{kg}^{-1}$ ) diets were increased by addition of synthetic lysine to a basal corn-soybean meal diet. The amount of lysine added was dependent on the respective treatment. Half of the grower diets of the pullets fed on a restricted feed intake were upgraded $(15 \%)$ with digestible lysine. The body weight and feed consumption of the pullets were recorded weekly per cage. From these data FCRs were calculated.

Results and discussion. The results of the experiments are presented in Table 2 . Pullets ( $0-6$ weeks of age) fed a diet with $0.65 \%$ digestible lysine (Treatments 3 and 4) had, on average, a $20 \mathrm{~g}$ lower body weight at 6 weeks of age than pullets fed a diet with $0.85 \%$ digestible lysine (Treatments 1 and 2). However this difference was not significant $(P>0.05)$. Feed intake within this period did not significantly differ among treatments, although the feed conversion ratio (FCR) was higher for pullets fed on the low lysine diet. No difference in feed intake was observed between pul-

Table 1. Digestible lysine content of the experimental diets.

\begin{tabular}{llll}
\hline Treatment $^{1}$ & \multicolumn{3}{l}{ Age (weeks) } \\
\cline { 2 - 4 } & $0-6$ & $7-15$ & $16-18$
\end{tabular}

Step-down $(A L)^{2}$

$\begin{array}{llll}1 & 0.85 & 0.67 & 0.57 \\ 2 & 0.85 & 0.67 & 0.67\end{array}$

Step-up $(A L)$

\begin{tabular}{llll}
3 & 0.65 & 0.67 & 0.77 \\
4 & 0.65 & 0.67 & 0.67 \\
Mid-term restriction & $A L$ & $R$ & $A L$ \\
5 & & & \\
6 & 0.85 & 0.79 & 0.77 \\
7 & 0.85 & 0.79 & 0.67 \\
8 & 0.85 & 0.67 & 0.77 \\
\hline
\end{tabular}

${ }^{1}$ Each treatment consisted of 5 replicates.

${ }^{2} \mathrm{AL}=$ ad libitum feeding level; $\mathrm{R}=$ restricted: $85 \%$ of $\mathrm{AL}$. 
Table 2. Means of least squares.

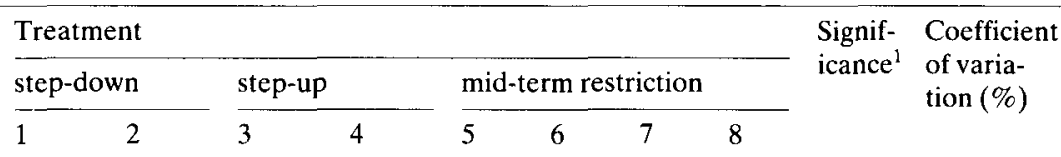

Body weight $(g)$

$\begin{array}{rllllllllll}6 \text { weeks } & 380 & 376 & 363 & 353 & 376 & 383 & 382 & 374 & \text { n.s. } & 4.89 \\ 15 \text { weeks } & 1095^{\mathrm{ab}} & 1100^{\mathrm{ab}} & 1095^{\mathrm{abd}} & 1105^{\mathrm{a}} & 1052^{\mathrm{c}} & 1048^{\mathrm{c}} & 1070^{\mathrm{bc}} & 1063^{\mathrm{dc}} & & 2.32 \\ 18 \text { weeks } & 1168 & 1172 & 1168 & 1174 & 1135 & 1151 & 1146 & 1160 & \text { n.s. } & 2.46\end{array}$

Cumulative feed consumption ( $g /$ hen housed)

\begin{tabular}{|c|c|c|c|c|c|c|c|c|c|c|}
\hline $0-6$ weeks & 871 & 865 & 850 & 844 & 857 & 861 & 874 & 851 & n.s. & 4.64 \\
\hline $7-15$ weeks & $3661^{a}$ & $3703^{\mathrm{a}}$ & $3637^{a}$ & $3622^{\mathrm{a}}$ & $3147^{b}$ & $3157^{b}$ & $3160^{\mathrm{b}}$ & $3163^{b}$ & & 97 \\
\hline $16-18$ weeks & $1294^{\mathrm{a}}$ & $1302^{\mathrm{a}}$ & $1284^{\mathrm{a}}$ & $1390^{\text {acd }}$ & $1459^{\mathrm{bc}}$ & $1554^{\mathrm{b}}$ & $1513^{\text {bd }}$ & $1588^{\mathrm{b}}$ & & .36 \\
\hline $0-18$ weeks & $5825^{\mathrm{a}}$ & $5870^{\mathrm{a}}$ & $5771^{\mathrm{a}}$ & $5856^{\mathrm{a}}$ & $5463^{\mathrm{b}}$ & $5572^{\mathrm{b}}$ & $5547^{\mathrm{b}}$ & $5601^{\mathrm{b}}$ & & 2.30 \\
\hline
\end{tabular}

Feed conversion ratio (FCR; $\mathrm{g}$ feed/g gain)

\begin{tabular}{|c|c|c|c|c|c|c|c|c|c|c|}
\hline $0-6$ weeks & $2.55^{\mathrm{ab}}$ & $2.55^{\mathrm{ab}}$ & $2.62^{\mathrm{bc}}$ & $2.68^{\mathrm{c}}$ & $2.52^{\mathrm{ab}}$ & $2.50^{\mathrm{a}}$ & $2.53^{\mathrm{ab}}$ & $2.53^{\mathrm{ab}}$ & & 3.30 \\
\hline $7-15$ weeks & $5.12^{\mathrm{a}}$ & $5.12^{\mathrm{a}}$ & $4.97^{\mathrm{ad}}$ & $4.82^{\mathrm{cd}}$ & $4.66^{\mathrm{bc}}$ & $4.75^{\mathrm{bc}}$ & $4.60^{b}$ & $4.60^{\mathrm{b}}$ & & 2.99 \\
\hline $16-18$ weeks & 17.90 & 18.61 & 19.10 & 21.10 & 17.64 & 15.98 & 19.93 & 15.77 & n.s. & 18.32 \\
\hline $0-18$ weeks & $5.16^{\mathrm{a}}$ & $5.16^{\mathrm{a}}$ & $5.13^{\text {acd }}$ & $5.17^{\mathrm{a}}$ & $4.96^{\mathrm{b}}$ & $5.02^{\mathrm{ab}}$ & $5.00^{b d}$ & $4.97^{\mathrm{bc}}$ & & 2.32 \\
\hline
\end{tabular}

${ }^{1} \mathrm{a}, \mathrm{b}, \mathrm{c}, \mathrm{d}$ Means in a row with the same superscript are not significantly different $(P>0.05)$.

lets fed on step-down and step-up regimes in the period from 7-15 weeks of age. Pullets subjected to the step-up regimes obviously converted their feed more efficiently during this period than the pullets fed on step-down regimes (Treatments 3 and 4 versus Treatments 1 and 2). A slight change of the lysine content in the diet after 15 weeks of age had no effect on growth and feed consumption.

Pullets on a restricted feed intake from 7-15 weeks of age (Treatments 5-8) showed a significantly lower body weight at 15 weeks of age than the ad libitum fed pullets. This was mainly due to the restricted allowance of feed. At 18 weeks of age, no significant differences in body weight were found between pullets of all treatments. 'Mid-term' restricted pullets (Treatments 5-8) consumed a significantly lower amount of feed over the whole rearing period than the qualitative restricted pullets. This is illustrated by the FCR values in Table 2. Mortality rate during rearing was on average $3.0 \%$ and did not differ among treatments.

The main advantage of a 'mid-term' feed restriction seems to be the ability to control growth during rearing (thus saving feed costs), while allowing pullets to compensate 'growth-loss' during the last part of the rearing period. The overall lower FCR values ( $0-18$ weeks; Table 2 ) of Treatments 5-8 can be explained partly by the possibility of a changed protein-fat deposition during the restriction period. This is in agreement with the results of Wells (1980), who promoted this method for rearing pullets.

Leeson \& Summers (1979) reported a significantly lower body weight at 20 weeks 
of age for step-up-reared pullets as compared to conventional step-down-reared pullets. The low digestible lysine level in our starter diet $(0.67 \%)$ was insufficient to cause a definite growth retardation and an accompanying decreased feed intake in the step-up groups.

From our experiments, it can be concluded that the feeding strategies used achieve equal body weights at 18 weeks of age, but result in different patterns of body-weight development (growth curves). After a thorough 'mapping' of the interactions between physiological and nutritional factors involving the maturing pullet, decisions about the use of specific feeding strategies during rearing can be made. However more research on the relation between growth curve and laying performance is desirable.

\section{References}

Leeson, S., 1986. Rearing leghorn pullets. 47th Minnesota Nutrition Conference and Monsanto Technical Symposium, Minnesota, USA.

Leeson, S. \& J. D. Summers, 1979. Step-up protein diets for growing pullets. Poultry Science 58: 681686.

Scott, M. L., M. C. Nesheim \& R. J. Young, 1982. Nutrition of the chicken. Cornell University, Ithaca, New York, USA.

Summers, J. D. \& S. Leeson, 1978. Dietary selection of protein and energy by pullets and broilers. British Poultry Science 19: 425-430.

Wells, R. G., 1980. Pullet feeding systems during rearing in relation to subsequent laying performance. Recent Advances in Animal Nutrition 1980: 185-202.

This synopsis is based on an undergraduate thesis 'Een onderzoek naar de invloed van lysine-deficiëntie in combinatie met voederbeperking of ad libitum voeding op groei-eigenschappen van opfokkuikens' by P. C. M. Z. Corijn, Department of Animal Nutrition, Wageningen Agricultural University, Wageningen, 1987. 30 pp., 3 figs., 4 tables, 23 refs., 9 appendices. Available as paper copy (order R083P, $f 10 \mathrm{in}$ cluding postage) at: NARD, clo Pudoc, P.O. Box 4, 6700 AA Wageningen (telex 45015 blhwg). 